\title{
Efficiency of Application of Mineral Fertilizers for Winter Wheat on Leached Black Chernozem
}

\section{Ksenia Moiseeva1, Alexander Karmatskikh¹, and Anastasia Moiseeva²}

${ }^{1}$ The State Agricultural University of The Northern Trans-Ural, Tyumen, Russia

${ }^{2}$ Tyumen State University, Tyumen, Russia

\section{Abstract}

The article considers the issue of productivity and economic efficiency of the use of slow-acting nitrogen fertilizers obtained using the "Si" technology of winter wheat. The studies were carried out in 2014--2017 in the northern forest-steppe zone of the Tyumen region on the experimental field of the Agrotechnological Institute of the GAU of the Northern Trans-Urals. increased winter wheat grain yield. Winter wheat productivity according to the studied options on average over the years of research ranged from 3.36--3.41 t/ha, which is higher than the control about the option of

Corresponding Author:

Ksenia Moiseeva

moiseeva.ks@mail.ru

Received: 25 October 2019

Accepted: 15 November 2019

Published: 25 November 2019

Publishing services provided by Knowledge E

(c) Ksenia Moiseeva et al. This article is distributed under the terms of the Creative Commons

Attribution License, which

permits unrestricted use and

redistribution provided that the

original author and source are credited.

Selection and Peer-review under the responsibility of the AgroSMART 2019 Conference Committee. 0.27--0.32 t/ha. The economic efficiency of the fertilizers used was determined by the cost of increasing the crop and the cost of obtaining it. Analysis of economic efficiency showed that when sowing the nitrogen fertilizer, urea encapsulated by $\mathrm{Si}$ technology (30 kg/ha d.v.) received the highest profitability -- $81.68 \%$. The resulting conditionally net income in this option amounted to $1663.4 \mathrm{rub} / \mathrm{ha}$. In the sixth version of the experiment (encapsulated urea according to the "Si" technology (60 kg/ha a.v.) + $\mathrm{KCl}\left(30 \mathrm{~kg} / \mathrm{ha}\right.$ a.a.) $+\mathrm{P}_{2} \mathrm{O}_{5}(40 \mathrm{~kg} / \mathrm{ha}$ a.a.)) profitability -- $76.0 \%$. Obtained conditionally net income in this embodiment amounted to 1222 rubles/ha. The return on fertilizer use ranged from 4 to $85 \%$.

Keywords: winter wheat, mineral fertilizers, productivity, economic efficiency, profitability.

\section{Introduction}

Ensuring food security of the Tyumen region is the most important strategic task of the agro-industrial complex. Winter crops are rightfully considered promising crops. According to the Department of Agriculture of the Tyumen Region, winter wheat productivity in the region increased from $2.11 \mathrm{t} /$ ha in 2016 to $3.15 \mathrm{t} /$ ha in 2018 .

Winter wheat has a high potential and responsiveness to the application of mineral fertilizers. At the present stage, the productivity of winter crops is not fully realized [1-4]. 
In connection with an increase in the supply of mineral fertilizers and the expansion of fertilized areas under crops, the introduction of the most effective doses and methods of using mineral fertilizers in the regions is of great importance $[5,6]$.

Many scientists believe that soil cultivation is considered one of the factors for increasing the productivity of grain crops [7, 8]. Meanwhile, as the materials of I.G. Yulushev, there is no alternative to fertilizers, without fertilizers it is impossible to work profitably on the land [9]. The main measures that take into account soil and climatic resources and biological characteristics of plants and increase the efficiency of the use of mineral fertilizers should be aimed at their scientifically-based, rational use, taking into account the results of agrochemical examination of soils, with the calculation of fertilizer doses for the planned crop [10--12].

High yields with good product quality, obtained using fertilizers, must meet the criteria of economic feasibility. Rational use of fertilizers allows you to recoup not only the costs of their acquisition and introduction, but also gives the economy a profit [13, 14].

\section{Methods and Equipment}

\subsection{Methods}

At the State Agrarian University of Northern Trans-Urals, a new technology for coating granules of nitrogen fertilizers with a water-insoluble silicate composition with the inclusion of a urease inhibitor has been developed $[15,16]$.

In this regard, the aim of the research is to study the effect of slow-acting nitrogen fertilizers on the productivity and economic efficiency of the use of slow-acting nitrogen fertilizers obtained using the "Si" technology of winter wheat.

For three years, a field experiment was conducted on the SAI test field of the Northern Trans-Urals to study the effect of mineral fertilizers on winter wheat productivity. The soil in the experiment is leached chernozem, the humus content is 7.65--9.05\%. In the experiment we studied the registered variety of winter wheat Novosibirsk 32 with six variants of fertilizer application according to the experimental design. The sowing date is the first decade of September (September 4--5). The repetition in the experiment is fourfold, the plot area is $30 \mathrm{~m}^{2}$. Agricultural technology generally accepted for culture in the region. The predecessor is pure steam.

Studied 6 options for experience:

1. No. 1 -- control (without fertilizing); 
2. No. 2 -- carbamide (60 kg/ha ai);

3. No. 3 -- encapsulated carbamide according to the "Si" technology (60 kg/ha ai);

4. No. 4 -- encapsulated carbamide according to the "Si" technology (30 kg/ha ai);

5. No. 5 -- encapsulated carbamide according to the "Si" technology $(60 \mathrm{~kg} / \mathrm{ha}$ ai $)+$ $\mathrm{KCl}$ (30 kg/ha ai);

6. No. 6 -- encapsulated carbamide according to the "Si" technology (60 kg/ha a.a.) $+\mathrm{KCl}\left(30 \mathrm{~kg} / \mathrm{ha}\right.$ a.a.) $+\mathrm{P}_{2} \mathrm{O}_{5}$ (40 kg/ha a.a.).

Fertilizers were applied simultaneously with sowing. Accounting and observations were performed in accordance with generally accepted methods, the results were processed by the dispersion method.

The economic efficiency of the production of winter wheat was evaluated by yield and the cost of obtaining it, using routings and guidelines.

\section{Results}

On average for 2014--2017 the yield of winter wheat in the control (without the use of fertilizers) was $3.04 \mathrm{t} / \mathrm{ha}$. The yield increases due to the use of the studied fertilizers of the experimental variants varied from $0.02 \mathrm{t} /$ ha to $0.51 \mathrm{t} / \mathrm{ha}$ (Fig. 1).

The highest grain yield of winter wheat over the years of research was noted in the sixth version of the experiment (urea encapsulated by "Si" technology ( $\mathrm{N}(60 \mathrm{~kg} / \mathrm{ha}$ a.a.) $+\mathrm{KCl}\left(30 \mathrm{~kg} / \mathrm{ha}\right.$ a.a.) $+\mathrm{P}_{2} \mathrm{O}_{5}$ (40 kg/ha a.a.)) -- $3.55 \mathrm{t} / \mathrm{ha}$, which is $0.51 \mathrm{t} /$ ha higher than the control version. This is $16.81 \%$ of the increase in yield. The yield in the third, fourth and fifth variants was close in magnitude and amounted to 3.36--3.411 t/ha, respectively, which is 0.27--0.32 t/ha higher than the control option (3.04 t/ha).

In 2014--2015 maximum yield was noted in the fourth embodiment, the urea encapsulated according to the "Si" technology (30 kg/ha a.a.) and amounted to $2.73 \mathrm{t} / \mathrm{ha}$. Yields on the fifth, third and sixth options are slightly lower -- 0.45; 0.37 and $0.31 \mathrm{t} / \mathrm{ha}$, respectively. In the second variant, a slight excess of the control variant by $0.17 \mathrm{t} / \mathrm{ha}$ was noted.

In the warmer 2016--2017. the maximum yield of winter wheat in the experiment was noted -- $4.58 \mathrm{t} / \mathrm{ha}$ when applying the sixth option, which is higher than the control by $0.71 \mathrm{t} / \mathrm{ha}$. Significant yield increases were obtained in options 3, 4, 5 and 6: excess of 0.19--0.49 t/ha over control. The exception was the second version of urea $(60 \mathrm{~kg} / \mathrm{ha}$ a.a.), where a decrease in yield of $0.13 \mathrm{t} / \mathrm{ha}$ was noted. 
The use of the studied nitrogen fertilizers increased the yield of winter wheat grain, except for the variant with fertilizers urea (60 kg/ha a.a.) -- $0.02 \mathrm{t} / \mathrm{ha}$. In general, for the studied options, the yield increase was from 0.66 to $16.81 \%$.

The economic efficiency indicators for the use of encapsulated carbamide according to the "Si" technology are presented in Table 1. The total amount of costs associated with the use of the studied fertilizers in the control version was 500 rubles/ha. The smallest amount of costs in the fourth option (urea encapsulated according to the "Si" technology (30 kg/ha ai)) -- 2037 rubles/ha. The largest amount of costs was noted in the sixth version of the experiment (urea encapsulated by "Si" technology $(60 \mathrm{~kg} / \mathrm{ha}$ a.a.) $+\mathrm{KCl}(30 \mathrm{~kg} / \mathrm{ha}$ a.a. $)+\mathrm{P}_{2} \mathrm{O}_{5}(40 \mathrm{~kg} / \mathrm{ha}$ a.a. $\left.)\right)--3878 \mathrm{rub} / \mathrm{ha}$.

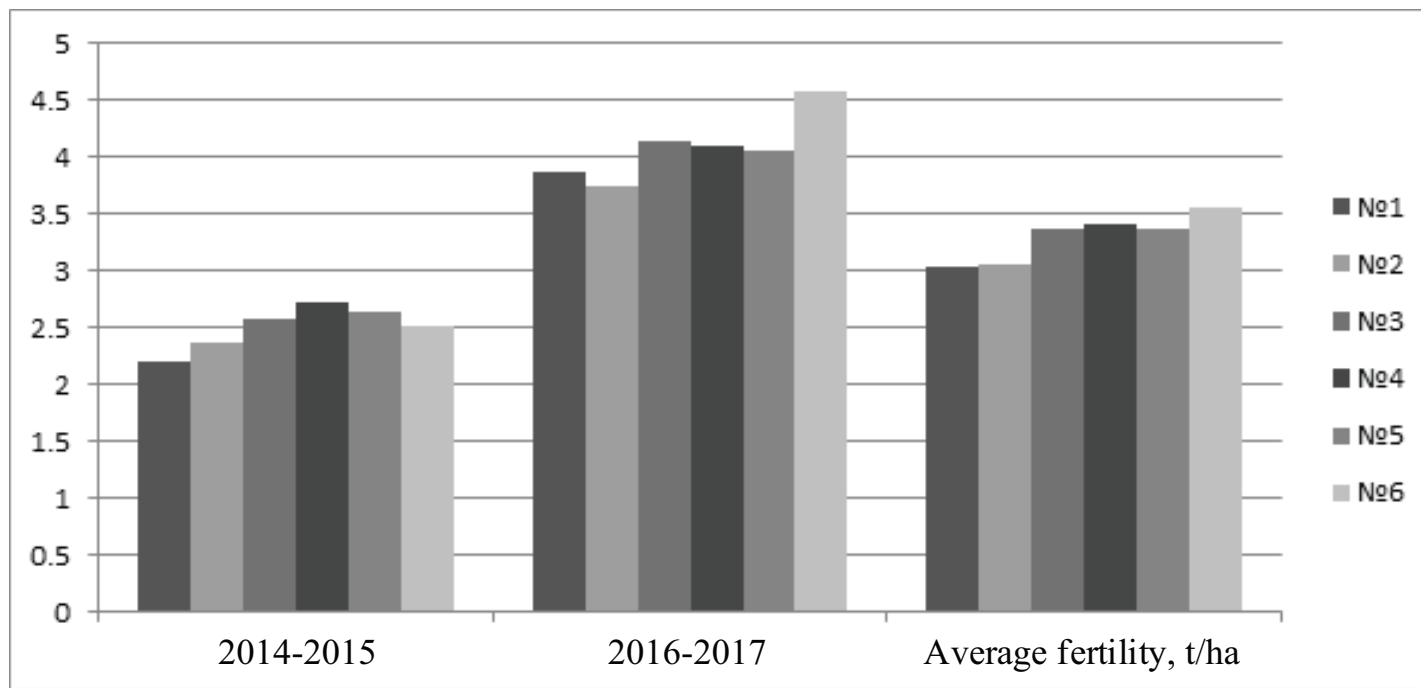

Figure 1: The yield of winter wheat, depending on the fertilizer used, 2014--2017.

TABLE 1: Economic efficiency of winter wheat production depending on the applied fertilizers (average for 2014--2017).

\begin{tabular}{|c|c|c|c|c|c|c|c|}
\hline № & Indicators & № 1 & № 2 & № 3 & № 4 & № 5 & № 6 \\
\hline 1 & $\begin{array}{l}\text { Productivity when applying } \\
\text { fertilizers, } t / \text { ha }\end{array}$ & 3,04 & 3,06 & 3,36 & 3,41 & 3,36 & 3,55 \\
\hline 2 & Yield increase due to fertilizers, $t / h a$ & $x$ & 0,02 & 0,32 & 0,37 & 0,32 & 0,51 \\
\hline 3 & $\begin{array}{l}\text { The cost of an additional crop from } 1 \\
\text { t, rub }\end{array}$ & $x$ & 200 & 3200 & 3700 & 3200 & 5100 \\
\hline 4 & Total cost, rub/ha & 500 & 2991 & 3526 & 2037 & 3773 & 3878 \\
\hline 5 & Conditionally net income, rub/ha & $x$ & --2797 & --326 & 1663 & --573 & 1222 \\
\hline 6 & Payback, \% & $x$ & 4 & 57 & $x$ & 85 & $x$ \\
\hline 7 & $\begin{array}{l}\text { The profitability of the use of } \\
\text { fertilizers, } \%\end{array}$ & $x$ & $x$ & $x$ & 82 & $x$ & 76 \\
\hline
\end{tabular}


An agrotechnical technique is considered economically viable if the proceeds from the sale of the grown products not only reimburse the costs of production, but also provide a net income. Thus, in our studies, 4 and 6 variants of the experiment are economically profitable when cultivating winter wheat.

\section{Discussion}

The economic efficiency of the fertilizers used was determined by the cost of increasing the crop and the cost of obtaining it.

Analysis of economic efficiency showed that when sowing nitrogen fertilizer, urea encapsulated by Si technology (30 kg/ha a.v.) received the highest profitability of $81.68 \%$. Received conditionally net income in this embodiment amounted to 1663.4 rubles/ha. In the sixth version of the experiment (urea encapsulated according to the "Si" technology (60 kg/ha a.a.) + KCl (30 kg/ha a.a.) + P2O5 (40 kg/ha a.a.)) profitability -$76,0 \%$. Obtained conditionally net income in this embodiment amounted to $1222 \mathrm{rub} / \mathrm{ha}$. In other versions of the experiment, no profit was obtained at such costs. There turn on fertilizer use ranged from 4 to $85 \%$.

\section{Conclusion}

In the conditions of the northern forest-steppe of the Tyumen region, in different weather conditions, a positive effect of encapsulated fertilizers (urea encapsulated by "Si" technology) on the productivity of winter wheat was established. According to calculations on economic efficiency, the fourth option was the most appropriate option -- encapsulated carbamide according to the "Si" technology (30 kg/ha a.a.) with a yield of $3.41 \mathrm{t} / \mathrm{ha}$, the profitability of which was $81.68 \%$.

\section{Funding}

The research was carried out on the experimental field (village of Uteshevo) of the Agrotechnological Institute of the Federal State Budgetary Educational Establishment of Higher Education State Agricultural University of the Northern Trans-Urals. 


\section{Acknowledgement}

The authors thank the head. Department of General Chemistry Komissarov I.D. and the collective department for the development of new technologies: granules of nitrogen fertilizers, sparingly soluble in water, a silicate composition with the inclusion of urease inhibitors in it. A.S. 1353767 USSR, MKI3 S 05 U 3/00 Method for the production of slow-acting fertilizers/Tyumen Agricultural Institute, author's study. I.D. Komissarov, L.A. Panfilov.

\section{Conflict of Interest}

The authors have no conflict of interest.

\section{References}

[1] Bashkov, A.S., Dzyuin G.P., Kutuzova I.A. (2012). The influence of the systemic use of mineral fertilizers on the yield of winter rye -- Agrochemistry in the Urals: history and modernity. Materials Vseros. scientific-practical Conf. dedicated to the 55th anniversary of the Department of Agricultural Chemistry and Soil Science. Izhevsk: FSBEI HPE Izhevsk State Agricultural Academy.

[2] Bannov, I.G. (2005). The effect of mineral fertilizers on productivity and grain quality of winter wheat varieties in the subzone of ordinary chernozems of the Volgograd region. Materials IX region. conf. young researchers of the Volgograd region. Volgograd: Volgograd State Agricultural Academy.

[3] Karmatskikh, A.A., Moiseeva K.V., Moiseeva A.A. (2015). The effect of nitrogen fertilizers on winter wheat grain productivity in the conditions of the Northern TransUrals. Materials of VII All-Russian. scientific and practical correspondence conf. young scientists "Development of scientific, creative and innovative activities of youth". Kurgan: Kurgan State Agricultural Academy.

[4] Moiseeva, K., Karmatskiy, A., Moiseeva, A. (2018). Influence of Mineral Fertilizers on Winter Wheat Yield. Effect of mineral fertilizers on winter wheat productivity. International scientific and practical conference "AgroSMART -- Smart solutions for agriculture" (AgroSMART 2018), pp. 499--503. DOI: https://doi.org/10.2991/ agrosmart-18-18.2018.94

[5] Sherstobitov, S. (2018). Efficacy of Offline Differential Fertilization by Ammonia Nitrate for Summer Wheat Growing. Efficiency of Autonomous Differential Fertilizer with 
Ammonia Nitrate for Spring Wheat Growth. International scientific and practical conference "AgroSMART -- Smart solutions for agriculture" (AgroSMART 2018), pp. 641--645. DOI: https://doi.org/10.2991/agrosmart-18-18.2018.120

[6] Kazak, A.A., Loginov, Y.P., Kendus, K.A. (2018). The Yield of Early Potato Varieties of Domestic Breeding, Depending on the Level of Mineral Nutrition in the Northern Forest-Steppe of the Tyumen Region. Yields of early-ripening varieties of domestic selection potatoes depending on the level of mineral nutrition in the northern forest-steppe of the Tyumen region. International scientific and practical conference "AgroSMART -- Smart solutions for agriculture" (AgroSMART 2018), 2018. pp. 321-326. DOI: https://doi.org/10.2991/agrosmart-18-18.2018.61

[7] Rzaeva, V., Fisunov, N., Miller, S. (2018). Crop Yields For Various Soil Treatment Variants in the Northern Forest-Steppe of Tyumen Oblast. Productivity of various tillage options in the northern forest-steppe of the Tyumen region. International scientific and practical conference "AgroSMART -- Smart solutions for agriculture" (AgroSMART 2018), pp. 606--609. DOI: https://doi.org/10.2991/ agrosmart-18-18,2018.113

[8] Shahova, O., Fisunov, N. (2018). Application of Various Primary Tillage Systems in Western Siberia. Application of various primary tillage systems in Western Siberia. International scientific and practical conference "AgroSMART -- Smart solutions for agriculture" (AgroSMART 2018), pp. 631--635. DOI: https://doi.org/10. 2991/agrosmart-18-18,2018.118

[9] Yulushev, I.G. (2005). Soil-agrochemical fundamentals of adaptive landscape organization of agricultural systems VKZP. Moscow: Academic Project.

[10] Azjurova, M.V. (2017). Economic efficiency of the use of mineral fertilizers in the region. Mat. International scientific and practical. conf. "Actual issues of the use of fertilizers in agriculture". Gorsky GAU.

[11] Eremin, D.V. (2018). Agro-economic assessment of mineral fertilizers used in the Tyumen region. News of the Orenburg State Agrarian University, no. 4(72), p. 26-30.

[12] Eremina, D. (2018). Agroeconomic Rationale for Applying Mineral Fertilizers to Cereal Crops in West Siberia. Agroeconomic rationale for the use of mineral fertilizers for cereals in Western Siberia. International scientific and practical conference "AgroSMART -- Smart solutions for agriculture" (AgroSMART2018), pp. 160--164. DOI: https://doi.org/10.2991/agrosmart-18-18, 2018.31

[13] Jobik, L.N. (2015). Agroeconomic efficiency of applying organic fertilizers based on waste from a biogas plant under barley on sod-podzolic sandy loam soil. Soil science 
and agrochemistry, no. 2(55), p. 125--137.

[14] Artyushin, A. M., Deryugin, I. P., Kulyukin A. N., Yagodin B. A. (1991). Fertilizer in intensive crop cultivation technologies. Moscow: Agroproimzdat.

[15] Kozel, E.G. (2000). Effectiveness of using a new form of encapsulated urea under table beets on leached chernozems of the Tyumen region. Cand. S.-kh. Sciences. Tyumen State Institute.

[16] Karmatsky, AA, Redozubov D.S. (2017). Review of urea-based fertilizers with controlled release of nitrogen. Bulletin of the State Agrarian University of the Northern Trans-Urals, no. 2(37), p. 63--66. 